\title{
TRACES OF CRITICAL SPIRITUAL PEDAGOGY IN INDONESIAN EFL TEACHERS' CHRISTIAN-BASED CLASSES
}

\author{
Aurelia Melinda Herka Puspita \\ (aurelia.melinda.h.p@gmail.com) \\ Joseph Ernest Mambu \\ (joseph.mambu@uksw.edu) \\ Universitas Kristen Satya Wacana - Fakultas Bahasa dan Seni \\ Jalan Kartini No.15-17, Salatiga, Central Java
}

\begin{abstract}
The incorporation of critical pedagogical (CP) perspectives into ELT classrooms has been widely discussed in ELT literature, but how English language teachers in Indonesian schools integrate them in their lessons has not been sufficiently documented. This study aims to investigate to what extent $\mathrm{CP}$ perspectives are integrated within the learning process to teach four basic English skills, although the teachers were not familiar with CP. Two in-service English teachers from a private junior high school in Central Java, Indonesia, filled in a questionnaire designed to identify their pedagogical identity. They were also interviewed and observed to further investigate their responses in the questionnaire and to explore the realization of the $\mathrm{CP}$ practice. The data was classified based on the components of critical language pedagogy proposed by Crookes (2013). The results showed that as students' wholeness was acknowledged, the learning process integrated cultural and critical contents to teach a particular language feature. During the learning process, there was a great deal of the inclusion of spiritual values as a way of demonstrating the students' criticality.
\end{abstract}

Keywords: critical pedagogy, critical spiritual pedagogy, criticality in EFL

DOI: http://dx.doi.org/10.15639/teflinjournal.v31i2/259-276

The practice of critical pedagogy (CP) where EFL classroom activities and learning are aimed at achieving social transformation (Akbari, 2008) has been 
applied in the higher education in Indonesia (see e.g., Mambu, 2009, 2011, 2016). Previous studies have suggested that integrating sociopolitical and cultural issues may improve students' awareness and understanding of how they realize their role and power as agents of change in society (Hooks, 1994; Kubota, 2014, 2016; Lim \& Keuk, 2018; López-Gopar, 2019; Murdock \& Hamel, 2016; Sharma \& Phyak, 2017). However, the issue of whether teachers realize that they have made use of their capacity to incorporate sociopolitical and cultural issues to teach the four basic English skills, listening, reading, speaking, and writing, has not been sufficiently addressed.

The practice of ELT has typically focused on the language features without teachers considering the importance of reflecting upon the surrounding sociopolitical and cultural contexts when explaining the relevance of the language features being taught (Moorhouse, 2014). This situation is referred to by Freire (1970/2000) as the banking concept of education where students are seen merely as storage of predetermined knowledge to be filled by the teachers.

Contrary to the banking concept of education, critical pedagogy has been viewed worthwhile to promote critical classroom discussions and activities in order for the students to be able to view the world surrounding them with better insights afterwards. Some of the guiding perspectives of the practice of critical pedagogy have been proposed by Murdock and Hamel (2016, p. 87), under the notion that a critical-pedagogy-based classroom should incorporate at least these three things: "(a) teacher's preparation for diverse classrooms, (b) mindful teaching, and (c) culturally relevant pedagogy."

Some scholars, including Larson (2014) and Mambu (2009, 2011), have already addressed the possibilities of incorporating $\mathrm{CP}$ in English language teaching, especially in EFL contexts in Indonesia. However, more empirical evidence is still necessary to see whether $\mathrm{CP}$ perspectives are integrated in Indonesian EFL classrooms, especially because most have not addressed how the practice is when it is broken down to teach four basic English skills. Therefore, this study specifically aims at examining whether, and the degree to which, EFL teachers in a junior high school in Central Java, Indonesia integrated critical perspective in teaching four basic English skills in their EFL classrooms. Thus, the investigation is focused more on the application of critical pedagogical perspectives in each of the English skills. By exploring ways of how teachers make use of the issues surrounding the students as sources of discussion in the classroom, it is hoped that more teachers will gain better insights into, in light of Chun and Morgan (2019), the feasibility of 
Puspita \& Mambu, Traces of Critical Spiritual Pedagogy 261

integrating $\mathrm{CP}$ perspectives to possibly transform the classroom, the community, and the broader society. It is also expected that this study will be beneficial for EFL teachers and educators who strive to teach based on the CP principles in their ELT classrooms.

In an attempt to achieve the research objective, in the following Review of Literature section, we discuss how $\mathrm{CP}$ has been conceptualized in the general education and ELT literature; how CP has been (claimed to be potentially) utilized in some ELT contexts; and the factors that might account for the use of $\mathrm{CP}$ in foreign language classrooms.

\section{Defining Critical Pedagogy}

The notion of CP is defined by Canagarajah (2005) as a way of doing learning and teaching. It promotes a different perspective of teaching and learning as it "seeks to understand and critique the historical and sociopolitical context of schooling and to develop pedagogical practices that are aimed not only to change the nature of schooling, but also the wider society" (Pennycook, 1999, p. 33). CP strives to uphold a more equal and just educational system where the learning is always contextualized to the relevant issues surrounding the society. Knowles and Lovern (2015) state that "it is the objective of Critical Pedagogy to expose and potentially change the structures of schools as an institution of society that promotes social inequities" (p. 19). CP builds upon a belief that the educational system, including an ELT classroom, has become not only a mirror of the surrounding wider system in society but also a site for teachers and students to initiate social change (Akbari, 2008).

Kincheloe (2008, p. 10) points out that CP is grounded in the view that education should promote justice and equality, as well as social change and intellectual development. It provides a platform where the students can also be sources and producers of knowledge. It focuses on pedagogies that allow students to raise awareness of themselves and values that shape them. $\mathrm{CP}$ is therefore committed to contextualizing learning to the surrounding where the educational activities occur as it pays close attention to people's experiences of being oppressed and dominated. In addition, the commitment of $\mathrm{CP}$ is to fight against the "harmful effects of dominant power" (ibid).

In view of Freire's (1970/2000) belief on education, the fundamental purpose of $\mathrm{CP}$ is to promote education as not simply the act of transmitting knowledge from the teacher to the students, but more as a process of 
consciousness-raising of the sociopolitical and cultural issues, as well as the injustices and discriminations in the society. In turn, it is hoped that the transformation in the wider society can happen through education (Akbari, 2008).

\section{Possibilities for Practicing Critical Pedagogy in Teaching English Skills}

The practices of $\mathrm{CP}$ for teachers to teach English skills have been reported in several previous studies, some of which focus on critical literacy in teaching reading (Fredricks, 2007), integrating CP perspectives in grammar lessons for a community-based ESL program catering for immigrants from Hong Kong in Canada (Morgan, 2004), using opinion-editorial articles to teach reading and writing (Mambu, 2011), and critiquing religious intolerance in a speaking class (Mambu, 2016). In Indonesia, a study done by Ikhtiar (2016) in a public junior high school in Salatiga has pointed out how problem posing, dialogue, and conscientization can be integrated within the English classroom.

It is possible to integrate $\mathrm{CP}$ principles to teach English skills (i.e., listening, speaking, reading, and writing) in the classroom. However, except the one done by Fredricks (2007), most of the previous studies have not specifically mentioned the possible activities which could be integrated to each skill. Some other publications have focused on the principles and guiding perspectives on CP (Hawkins \& Norton, 2009; Larson, 2014; Mambu, 2009, 2011). Hence, this current study is intended to provide a clearer overview on how the principles of $\mathrm{CP}$ are applied on each English skill being taught in a junior high school EFL classroom.

The practice of CP is strongly affected and determined by the society and the social background of the teacher and the students. In Indonesia, for example, there is Pancasila (or the five state principles) as the official, fundamental, and philosophical principles of the state. The principles embrace the five core values of spirituality, humanity, national unity, democracy, and social justice. Moreover, Indonesia is a diverse country where there are hundreds of different ethnicities and societies, each of which has their own values and beliefs. With the complexities, there are two major things, namely spirituality and culture, which may affect the practice of CP in the context of language learning in Indonesia.

Akbari (2008) explains that culture is an essential element of language learning as it is a tool to help the students familiarize themselves to the 
language features being learned. From a $\mathrm{CP}$ perspective, exploration of one's own culture through a target language being learned (e.g., English) allows the students to be aware of "negative and positive features of their [own] culture" (p. 279) and in turn envision socio-cultural transformation in the society.

Another factor which needs to be considered is the place of spirituality in the foreign language classroom in Indonesia. Ryoo et al. (2009) evaluate the notion of spirituality as a broad concept which concerns the "philosophy of becoming" where one is able to become the "Other to itself" and transcend their own being (p. 135). Ryoo et al. (2009) embrace the possibility of integrating spirituality in learning. It is expected that the teacher and students would be able to "nurture an inner development while simultaneously being critical of the world" in order for them to "seek justice and wholeness for [themselves] and the community at large" (p. 142).

A recent study conducted by Mambu (2016) in a Christian university in Java, Indonesia, investigated the students' self-negotiation between their religious identities and the "spiritually associated power relation in ELT settings" (p. 158). He pointed out how interfaith dialogue in ELT contexts was able to help students to critically negotiate their religious views, from which their sense of spirituality was derived. In Indonesian education, where the absolute oneness of God is believed as it is written in the Pancasila, addressing the connection between spirituality and criticality would be closely related to the teacher and students' religion.

\section{Theoretical Framework}

To better capture moments in which EFL teachers integrate $\mathrm{CP}$ perspectives in their classes, we draw from Crookes' (2013) "critical language pedagogy" components as the guiding principles, namely: language functions; task-specific needs; teacher planning; democratic classroom management; critical stance by the teacher; critical needs analysis; negotiated syllabus; codes or codifications; critical content in materials; democratic, participatory, and critical assessment; and action orientation.

Kincheloe's (2008) philosophies underlying CP (see the Defining Critical Pedagogy section) and Crookes' (2013) discussion about critical language pedagogy constitute the theoretical framework. Besides that, the component of critical stance by the teacher in Crookes' (2013) framework might include 
teachers' spirituality in guiding their criticality (Mambu, 2016; Ryoo et al., 2009).

\section{METHOD}

This study aims at answering these questions: whether the EFL teachers at a junior high school in Central Java, Indonesia, integrated any CP perspectives when teaching basic English skills, and if yes, how they did it. A case study was conducted in order to address the questions. Griffee (2012) explains that a case study deals with a limited and focused scope intended to examine something of a real-life context thoroughly.

The study was conducted at a private Christian junior high school. The students of the school were familiar with English since the language was used extensively at school. English learning was organized in a way that each skill was taught separately so that students would be able to understand the language features for each skill well.

The participants were two in-service English teachers at the school. To keep the identity of the participants confidential, Mr. Doni and Mr. Jojo are used as pseudonyms. Both participants generally believed that the practice of ELT could not be exclusively separated from the inclusion of the surrounding values that shape the language. They, however, seemed to be clueless with the notion of CP. Nonetheless, there have been indications of the practice of $\mathrm{CP}$ during the classroom activities that they did.

This study employed three data collection methods: questionnaire, interview, and classroom observation. To trace the pedagogical identity of the teachers in the junior high school, we used a questionnaire that was developed based on Crookes' (2013) components of critical language pedagogy. The questionnaire consisted of both closed-ended and open-ended items. The closed-ended items were used to find out mainly about the participants' background and approach(es) to English language teaching they claimed to be familiar with or have used, while the open-ended items were to probe into and identify more specifically on (a) what themes were incorporated to teach a particular unit; (b) materials development (including textbook choice); (c) classroom management and students' involvement in learning; (d) language assessment; and (e) what English language learning activities outside the classroom setting were expected to be done by students. 
Semi-structured interviews were conducted in order to follow up the answers in the questionnaire, as well as to probe into the participants' attitude and behavior related to their teaching practices. The obtained data was then translated into English from Bahasa Indonesia. Observations were conducted to trace the implementation of $\mathrm{CP}$ to teach the four English skills during classroom activities. From the observations, some parts of the learning process were audio-recorded with consent from the teachers and students. The parts which were recorded were mainly when classroom discussions and verbal interactions between the teacher and students occurred, especially when students were encouraged to take active part to articulate their thinking.

The data from the interview and observation were transcribed accordingly. A piece of data was considered relevant if it was parallel with the guiding principles of $\mathrm{CP}$ (Kincheloe, 2008) and components of critical language pedagogy suggested by Crookes (2013). The data was deemed significant if the application of the components can be seen from the selection of activities and materials during the learning process in the classroom.

\section{FINDINGS AND DISCUSSION}

From the questionnaire and interviews, the teachers participating in the current study somehow implemented $\mathrm{CP}$ in a way that the learning processes at a local context, in line with López-Gopar (2019), involved the teachers' sharing knowledge beyond the language features through critical dialogues and discussions with the students. The lessons were conducted not only to stimulate the students' linguistic cognition, but also, similar to what Parba and Crookes (2019) have articulated in their study, to unpack the relevance of the language features as a means of investigation of the current emerging issues which require attention. Based on the ideas which have already been proposed by Kincheloe (2008, p. 10), there are several key points in the data obtained from the questionnaire and interview.

\section{Promoting Justice and Equality and Reading the Word and the World}

Mr. Doni explained how he attempted to accommodate his students' need and bridge language barriers between students, especially when countering verbal bullying by their peers in the classroom. This is an indicator that he promotes justice and equality; as he suggested: 
If there is a student who does not understand English well, and speaks more slowly than the rest of the class, the student will be regarded as a slow learner. Sometimes on cases of mispronunciation, students who know how to pronounce correctly will make fun of the mistakes. (Interview session, March 8, 2017)

Mr. Doni also described how this situation might make some students felt disregarded. To deal with this, he initiated a solution by making an agreement with the whole class that the students should respect each other and help those who find difficulties in coping with the learning pace. Through this, he could generate a more cooperative classroom atmosphere (see Crookes, 2013) since the students can become tutors for their peers. In a way, the source of knowledge also comes from the students as they learn and develop each other's language competence (see Kincheloe, 2008). This also supported Akbari's (2008) argument upon the core value that CP holds, which is the respect for human dignity (p. 282).

Another finding indicating respect towards the students is initiated by $\mathrm{Mr}$. Jojo when dealing with a student who found it hard to follow the lesson. Mr. Jojo initiated to approach the student personally so that he could help his student better. He stated:

The reason why it was hard for him was because of his lacks of English knowledge. He almost failed and almost dropped out, so I changed the way I approached him when it was almost the end of the last semester. (Interview session, March 8, 2017)

Another indicator of $\mathrm{CP}$ implementation is the contextualization of learning materials to the students' surroundings. Mr. Doni explained the importance of including global issues which were different from the ones they have around them so it would give the students a better insight and new learning experience. He stated that within the educational system, sometimes the learning materials were focused only on a particular culture and hence excluded the fact that in different places there might be different issues. This could be a problem because it was hard to explore the learning further as he had to keep up with the government's predetermined curriculum. Rooms for improvements were still highly limited and insufficient. However, Mr. Doni attempted to incorporate as many sources as possible. From the interview, he revealed how the integration of the students' surrounding culture was possible during a classroom dialogue. The discussion would include the culture of the global community which in turn encouraged the students to compare it with 
their surroundings. The students would also learn, not merely about the language features, but also the fact that there is a lot more beyond what they have perceived previously; as he put it:

If we pay attention, many sources would suggest that the culture should be those from Indonesia, and it would be taught in English. Then, the dialogue would also be usual dialogue, like daily activities. This kind of learning would not give something new to the students. What I meant by global community is on how we discuss what is out there, and what makes it different from the ones we have around us. (Interview session, March 8, 2017)

As for Mr. Jojo, the contextualization of the learning materials was implemented during school field study activities. The students would go to places to observe and work on a project. When doing so, the students would be exposed to a different environment beyond the classroom. The contextualization of learning materials was possible as the students made use of their experience during field study to learn the language features taught previously in the classroom. He commented:

There were occasions when the students did outdoor observation. We had many field trips where we asked the students to observe and integrate it with the other subjects. I cooperated with the other teachers to create assignments for the students. Whenever possible, I will relate the assignments that I give to the students' daily life. (Interview session, March 8, 2017)

Kincheloe $(2008$, p. 10) also points out that a critical-pedagogy based classroom is also focused on bringing up the awareness to read the word and the world through the process of understanding oneself. Accordingly, the way the students in the junior high school viewed the world around them was more or less affected by what values had been taught to them. In this case, the context of the school being observed is a Christian-based private school relying its core value deeply on the Bible. In other words, the critical perspectives of the school member are shaped and affected strongly by the teachings taught in the Bible. It may be safe to say that the values of Christianity are utilized as the teacher's basis of demonstrating criticality.

Mambu (2017) argues that religious views like those of Christianity are possible sources of spirituality. Spirituality grounded in Christianity can be one's guiding principle to express his/her criticality. For example, in an observed classroom on April the $18^{\text {th }} 2017$, Mr. Doni brought up the issue of the governmental election in Jakarta to teach the students how to properly use 
$5 \mathrm{~W}$ and $1 \mathrm{H}$ question words. He connected the lesson to the value of authenticity and how it was reflected in the Bible. In this case, the common sense between Mr. Doni and the students in terms of their religion and belief was developed during the language learning. Most of the time, Mr. Doni would relate the lesson to how the students view the issue from the eye of Christianity. By doing so, the students were encouraged to think more deeply of what is true and/or untrue based on what has been taught by the source of their thought, that is, Jesus Christ and the Bible, as Mr. Doni stated:

... what matters is in here, we are a Bible based Christian school. On a particular topic I sometimes asked the students to reflect: 'Is there people's way of life in there? Then, as a Christian, do we also have a way of life? And does the way of life affect our behavior towards others who like and dislike us?' (Interview session, March 8, 2017)

Mr. Jojo generally did the same. When asked about the value integrated with the language learning, he mentioned that some values taught from the Bible were also integrated.

The values that I always integrated are Christian values, for sure. Yet it does not always mean that everything has to be from the Bible. Other than that, usually when discussing questions, I encouraged the students to think, because sometimes there are confusing questions, so students can learn to evaluate themselves. (Interview session, March 8, 2017)

Besides all of the indicators mentioned previously, some more guiding principles of CP suggested by Kincheloe (2008, p. 10) also include the way the classroom stakeholders are concerned with keeping the balance between social transformation and intellectual improvement, and being committed to promoting social justice by shaping the education and knowledge construction to resist social discrimination. These principles emerged in practice during the data collection process, especially during observations. The discussion will be further elaborated in the following sections, in which Crookes' (2013) components of $\mathrm{CP}$ are broken down to the learning application on each of the four English skills.

\section{Task Specific Needs}

Among the components proposed by Crookes (2013), the first one which was noticeable was on how Mr. Doni gave and presented tasks in a way that 
met the students' need and capacity. He attempted to facilitate the students by delivering the lesson using strategies that were comfortable for the students to follow. Mr. Doni mentioned cooperative learning, such as group works and group projects, as one of the major strategies to teach. On a further discussion about the realization on each skill, Mr. Doni responded:

For example in speaking, it can be expected that the students will not just listen, but also give advice if there is mispronunciation. The implementation may not be easy because sometimes there are students who are unwilling to help their friends. In writing, usually cooperative learning is possible in joint projects. The students can comment on and correct each other's works, so the less active students can improve their writing skill if they are too shy to ask their teacher. In reading, they can work in groups or pairs to answer questions. They can complement the things that one student might get while the others might not, and vice versa. In listening, usually the reflective task is in the form of drama, so it is an integration of speaking and listening. (Interview session, March 8, 2017)

In Mr. Jojo's case, usually the task was integrated so that all of the skills could be observed at one time.

For communicative purpose, usually it is more to the speaking skill, but it depends on the topic. I once assigned the students to create a video about Indonesian culture, and then present it, so all of the skills could be observed. (Interview session, March 8, 2017)

Both Mr. Doni and Mr. Jojo pointed out how the students were on different levels of language competence. Group work was one of the tools to develop better language competence as it would allow discussions to occur between students. The students would be able to improve their competence in a way that they became more focused, confident, and comfortable in practicing the language, as the students worked with only few classmates.

\section{The Negotiated Syllabus}

For the negotiated syllabus, Mr. Doni and Mr. Jojo had not elaborated far up to the point where the students could bring major changes to the overall syllabus, since they still had to follow the national curriculum. Yet, there were times when the students proposed some classroom activities such as games which involved movements. In an interview session conducted on March the $8^{\text {th }}$ 2017, Mr. Doni mentioned that once, the students were involved in a 
negotiation for writing rubric for the assignment. The students would make use of the rubric to assess their peers before their works were given to Mr. Doni.

\section{Language Functions and Critical Content in Materials}

Based on the observations in Mr. Doni's class, the data showed that when teaching language functions of questioning, a topic which triggered the students to think critically was integrated. The skills focused at that time were listening and speaking. English was used as medium of instruction. The phenomenon concerning the then Jakarta governor candidate, Basuki Tjahaja Purnama, known better as Ahok, was used for discussion. The language feature being taught was question words, with the heading of "Being a Journalist." During the discussion in class, there was a moment when the notion of injustice and discrimination experienced by Ahok was discussed.

At the beginning of the class, Mr. Doni assigned the students into groups of four. Then, he played two videos about the upcoming governmental election and the trial which Ahok was going through. Then, based on the group divisions, Mr. Doni asked the students to make sentences using $5 \mathrm{~W}$ and $1 \mathrm{H}$ question words, and answer the questions themselves. After that, the students presented the results of their discussion in front of the class. Below is the presentation from one of the groups being observed:

Peter (a pseudonym): So, here is the question and answer from our group. First, who is Ahok's opponent? He is Anies Baswedan. Two, what is Ahok's problem? $\mathrm{He}$ is blamed for talk bad things about the Islam religion. Three, where will the election happen? In Jakarta province. Four, when is the day of government election? It's on April 19, 2017. Five, why Jakarta people blame Ahok? Because Ahok make people who believe Islam angry. Six, how can the problem be over? Jakarta people have to see Ahok's talent, not only his mistake. (Transcribed verbatim from a classroom observation on April 18, 2017, with grammatical errors being not corrected)

After all of the groups had presented, Mr. Doni asked several reflective questions and summed up the whole learning experience. He also related the lesson to a specific value that the students should learn from.

So, today, we learn about how to make appropriate question using $5 \mathrm{~W} 1 \mathrm{H}$ question words. But, [I] want to tell you something that you should learn from today's lesson. That is about being honest, or we may say authentic. So being authentic means you say what is true, and sometimes, it can be risky. Sometimes 
people are not ready to accept the truth. That is one of the reason why the case happen to Ahok.

Nana (a pseudonym): So, not because Ahok is Chinese, Mr? or because he is not Islam?

Mr. Doni: They are the other reasons. But I want you to think more than that. Sometimes, when you tell the truth, people will dislike you. Ahok is a very straightforward person. That is why many people sometimes get hurt, so the discrimination happened. In the Bible, you can also see, Jesus Christ, He was disliked by many people because He told about love, He even asked them to love their enemy. Many people at that time did not understand, and they blamed Jesus for that. But it doesn't mean we should not be honest to protect ourselves. We should not be afraid, as long as we really tell the truth and have good intention, to help other people. Of course, it is really difficult, but if you start from yourself, you can be good examples for others. (Classroom observation, April 18, 2017, grammatical errors are not corrected)

When asked on a further interview to find out the reason why Mr. Doni chose the topic to teach the language function of questioning, he explained:

That was my initial reason for them to learn about authenticity. They have to accept that sometimes the people that we trust can hurt us without even realizing it. The world is not a perfect place, but I want to teach them that no matter what, do good anyway. That is why I used Ahok as an example, sometimes even our good intention could not be accepted. The problem is not only because he is a minority. That is just another reason which could corner him even more. He is a straightforward person, so maybe a lot of people could not match his personality. The point is I want the kids to learn that no matter how hard it is, they should follow the good, like what Jesus Christ has taught, to love. (Interview session, April 21, 2017)

According to Mr. Doni's answer, it is safe to infer that the critical perspectives of the students were shaped and affected by what they have learned from Jesus. The issue raised was reflected in a way that met the desired attitude of how the disciples of Jesus should be. Even though spiritual values were incorporated, it could still be sensed that the students were still able to critically address the issue while learning the language. 


\section{Critical Needs Analysis and Critical Stance by the Teacher}

The critical needs analysis was also visible as Mr. Doni noticed the problem of injustice and discrimination in his very class. With bullying cases happening in the class, Mr. Doni did a critical needs analysis by addressing the issue and encouraging the students to take part in finding the best solution to the problem together. As the issue occurred directly in class, it could be presumed that the student did not even need realia, since they experienced the bullying cases themselves. Besides that, the critical content also included the audiovisual materials, which were the videos about Ahok as the learning resources.

The notion of critical stance refers to how the teacher constantly develops criticality through various ways such as reading critical issues, keeping up with the current sociopolitical and cultural issues in the surroundings, or even blending in with the society where discrimination and injustice cases happens. Based on the data obtained, it could be concluded that the critical stance was found and exercised by referring to Jesus as a figure who fights for justice. As the Bible is the source of understanding, it is safe to say that the critical stance was developed based on the constant activities of referring the lesson and the issue raised during the lesson to the values taught in the Bible.

Beyond the choices of materials and activities which integrated critical perspectives, the teacher should first have a strong basis of critical stance of his own so that he could share the perspectives in a more developed and consistent way. From the interview and observation, the data shows that in many occasions, the teachers would integrate spiritual perspectives to reflect upon the lesson that the students learn in a particular meeting. Criticality could still be addressed and demonstrated, to the extent that the teachers, in some occasions, related the lesson to biblical verses in order for the students to have better insights towards their surroundings. It could then be assumed that the hope is for the students to bring changes and improvements to their surroundings based on what they perceived as Christians.

Moreover, taking a look further on Jesus Christ as a major role in the Bible, the students could actually learn about the notion of transformative initiatives since Jesus himself played a major role in revolution and transformation in His time. Jesus' model has inspired a notable CP scholar like Freire (1984) to theorize the notion of prophetic church. Freire emphasized how Christ Himself was "no conservative" and a prophetic church should 
constantly move forward, be "forever dying and forever being reborn" (p. 544). The expectation was for the students to at least reflect the values and bring changes for themselves. In short, demonstrating criticality without neglecting the students' religious identity is not impossible.

\section{CONCLUSIONS}

Overall, the findings show several indicators of the implementation of $\mathrm{CP}$ principles within the classroom activities and learning process, although the teachers were not yet familiar with the notion of CP. In many classroom settings, the students' dignity was acknowledged, proven by the fact that when a bullying problem occurred in the classroom, an agreement with the students in the classroom was made so that everyone would feel that they were responsible for keeping the learning process comfortable for everyone. The data also showed the importance of integrating the learning of various cultures to help make the students aware of their surroundings, in the hope that they would learn beyond the language. Based on the components proposed by Crookes (2013), under the notion of task specific needs and negotiated syllabus, the data obtained indicated that cooperative learning was practiced to teach the basic English skills, through the various activities involving group works. The negotiated syllabus was not very apparent, except that the teachers negotiated with the students to decide upon what classroom activities were preferred in class.

From the observation, the data revealed the integration of critical content to teach a language function. This suggests that the students not only learned about the target language and how to use it, but also increased their understanding and attentiveness towards the current issue or phenomenon around them. Another perspective integrated and demonstrated throughout the classroom activities was the teachers' and the learners' spirituality as reflected in their Christianity. In many situations, the reflections upon the lesson were related to Biblical values. Thus, it is possible to develop critical perspectives without leaving behind the spiritual values that ELT stakeholders hold.

Even though the major social transformation would be too far to reach in a short period of time within this study, it has always been the hope that the approach in the foreign language learning will enlighten the students on the views of the world. For further research, it is also expected that the elaboration on cultural and spiritual values influencing the critical perspectives, especially 
in Indonesia, would be better addressed as the practice of CP could never become exclusive to criticality in a cognitive sense. As this study has examined the application of CP in teaching English skills, further possible research may dig deeper upon the forms of transformations that occur, in the classroom and society, as a result of CP implementation.

\section{REFERENCES}

Akbari, R. (2008). Transforming lives: Introducing critical pedagogy into ELT classrooms. ELT Journal, 62(3), 276-283.

Canagarajah, S. (2005). Critical pedagogy in L2 learning and teaching. In E. Hinkel (Ed.), Handbook of research in second language teaching and learning (pp. 931-949). Lawrence Erlbaum.

Chun, C. W. \& Morgan, B. (2019). Critical research in English language teaching. In X. Gao (Ed.), Second handbook of English language teaching (pp. 1091-1110). Springer.

Crookes, G. V. (2013). Critical ELT in action: Foundations, promises, praxis. Routledge/Taylor-Francis.

Fredricks, L. (2007). A rationale for critical pedagogy in EFL: The case of Tajikistan. The Reading Matrix, 7(2), 22-28.

Freire, P. (1970/2000). Pedagogy of the oppressed (M. B. Ramos, Trans.) (30th anniversary edition). Continuum Books. (Original work published 1968).

Freire, P. (1984). Education, liberation, and the church. Religious Education: The Official Journal of the Religious Education Association, 79(4), 524545 .

Griffee, D. T. (2012). An introduction to second language research method: Design and data. TESL-EJ Publications.

Hawkins, M., \& Norton, B. (2009). Critical language teacher education. In A. Burns \& J. C. Richards (Eds.), The Cambridge guide to second language teacher education (pp. 30-39). Cambridge, UK: Cambridge University Press.

Hooks, B. (1994). Teaching to transgress: Education as the practice of freedom. Routledge.

Ikhtiar, T. P. W. (2016). Incorporating critical pedagogy through problem posing, dialogue, and conscientization in a junior high school in Salatiga. In C. Rudianto, E. Rudiyanto, L. Salvadora, A. M. H. Puspita, \& R. Maulidia (Eds.). Proceedings of the First Faculty of Language and 
Puspita \& Mambu, Traces of Critical Spiritual Pedagogy 275

Literature Student Conference on English Language Teaching \& Literature: Language: Promoting Value Education (pp. 94-106). Satya Wacana University Press.

Kincheloe, J. L. (2008). Knowledge and critical pedagogy: An introduction. Springer.

Knowles Jr, F. E., \& Lovern, L. L. (2015). A critical pedagogy for native American education policy. Palgrave Macmillan.

Kubota, R. (2014). "We must look at both sides"-but a denial of genocide too? Difficult moments on controversial issues in the classroom. Critical Inquiry in Language Studies, 11(4), 225-251.

Kubota, R. (2016). Critical content-based instruction in the world language classroom: Critical issues for implementation. In L. Cammarata (Ed.), Content-based foreign language teaching: Curriculum and pedagogy for developing advanced thinking and literacy skills (pp. 192-211). Routledge.

Larson, K. (2014). Critical pedagogy(ies) for ELT in Indonesia. TEFLIN Journal, 25(1), 122-138.

Lim, S., \& Keuk, C.N. (2018). A sociocultural analysis of Cambodian teachers' cognitions about cultural contents in an 'internationally imported' textbook in a tertiary English learning context. In H. P. Widodo, M. R. Perfecto, L. V. Canh, \& A. Buripakdi (Eds.), Situating moral and cultural values in ELT materials (pp. 87-110). Springer.

López-Gopar, M. E. (2019). Introducing international critical pedagogies in ELT. In M. E. López-Gopar (Ed.). International perspectives on critical pedagogies in ELT (pp. 1-15). Cham, Switzerland: Palgrave Macmillan.

Mambu, J. E. (2009). Thematic investigations with Indonesian EFL teachers: From descriptions to social critiques and beyond. Indonesian Journal of English Language Teaching, 5(1), 57-80.

Mambu, J. E. (2011). English for advocacy purposes: Critical pedagogy's contribution to Indonesia. The Journal of Asia TEFL, 8(4), 135-173.

Mambu, J. E. (2016). Investigating students' negotiation of religious faiths in ELT contexts: A critical spiritual pedagogy perspective. Critical Inquiry in Language Studies, 13(3), 157-182.

Mambu, J.E. (2017). Creatively negotiating the place of spirituality in the ELT classroom. TEFLIN Journal, 28(1), 93-114. 
Moorhouse, B. L. (2014). Using critical pedagogies with young EFL learners in a Hong Kong primary school. International Journal of Bilingual and Multilingual Teachers of English, 2(2), 79-90.

Morgan, B. (2004). Modals and memories: A grammar lesson on the Quebec referendum on sovereignty. In B. Norton \& K. Toohey (Eds.), Critical pedagogies and language learning (pp. 158-178). Cambridge University Press.

Murdock, D., \& Hamel, E. (2016). I would quit my job: Unpacking preservice teachers' perceptions of culture and diversity. International Journal of Critical Pedagogy, 7(2), 85-106.

Parba, J., \& Crookes, G. (2019). A Filipino L2 classroom: Negotiating power relations and the role of English in a Critical LOTE/World Language classroom. In M. E. López-Gopar (Ed.). International perspectives on critical pedagogies in ELT (pp. 59-78). Palgrave Macmillan.

Pennycook, A. (1999). Introduction: Critical approaches to TESOL. TESOL Quarterly, 33(3), 329-348.

Ryoo, J. J., Crawford, J., Moreno, D., \& McLaren, P. (2009). Critical spiritual pedagogy: reclaiming humanity through a pedagogy of integrity, community, and love. Power and Education, 1(1), 132-146.

Sharma, B. K., \& Phyak, P. (2017). Criticality as ideological becoming: Developing English teachers for critical pedagogy in Nepal. Critical Inquiry in Language Studies, 14(2-3), 210-238. 